\title{
Sustainable groundwater exploitation in Nigeria
}

\author{
David O. Omole
}

Department of Civil Engineering College of Science and Technology, Covenant University, Canaanland, Km 10 Idiroko Road, Ota, Nigeria

\section{Email address:}

david.omole@covenantuniversity.edu.ng,omojohnny@yahoo.com

\section{To cite this article:}

David O. Omole. Sustainable Groundwater Exploitation in Nigeria. Journal of Water Resources and Ocean Science. Vol. 2, No. 2, 2013; pp. 9-14. doi: 10.11648/j.wros.20130202.11

\begin{abstract}
In this study, a critical review of the groundwater resources history and management in Nigeria was done. The aim was to identify reasons why groundwater is increasingly being exploited in recent times, and to explore ways through which the exploitation could be done sustainably. This was achieved through literature review. It was observed that an estimated $60 \%$ of Nigeria's population get drinking water from ground resources. This high statistic is mostly the resultant effect of infrastructural decay in the potable water supply sector of the country. In Nigeria, just $14 \%$ of the country's population get regular water supply through piped sources while the remainder of the country's 162.5 million people draw their water supply mainly from surface and groundwater sources. Groundwater, in Nigeria, is accessed mainly in form of shallow (hand-dug) and deep (boreholes) wells. Well water withdrawal activities are mostly un-regulated and, therefore, the water sources are often subjected to avoidable abuses and pollutions. In particular, rapid urbanization, agricultural and industrial activities are major contributors of pollutions to groundwater sources. Also, unavailability of data such as geographical information on water quantity, hydrology, state of aquifer and withdrawal limits have contributed to the unsustainable use of groundwater in Nigeria. It was recommended that proper regulation of groundwater resources and its protection under the land use act of 1978 could be instrumental to its sustainable exploitation.
\end{abstract}

Keywords: Groundwater, Sustainable, Sub-Sahara Africa, Nigeria, MDG, Exploitation

\section{Introduction}

The unsustainable abstraction of groundwater has recently become a subject of global debate[1]. It is an issue that became prominent when global water consumption increased by nearly $1000 \%$ within a space of 50 years (1950-2000), mainly as a consequence of agricultural irrigation in[1]. According to $\mathrm{OECD}[2]$, agriculture is responsible for the use of $70 \%$ of all freshwater including groundwater. Factors which have made groundwater use quite attractive for agricultural is the relatively cheap cost of getting the water to the farm by sinking boreholes on location rather than piping or channelling the water over long distances[1]. Other contributing factors include cheap technology, breakdown of public utilities, the relative clean state of GW, and rapid and unplanned urbanization which makes new connection to public utilities nearly impossible[1]. Other causes are municipal and industrial supplies respectively. It is reported that more than half the world population obtain drinking water from groundwater sources[3-4]. GW has been instrumental to the partial success of millennium development goal 7c (MDG7c) which aims at reducing by half the number of people in the world without access to clean water and improved sanitation. The target for water was reached in 2010, five years ahead of the deadline of 2015. Today, only an estimated 783 million people are yet to have access to clean drinking water, with over 2 billion people gaining access between 1990 and 2010[5].

Prominent among countries where the MDG on clean drinking water has not been reached are sub-Saharan African countries (Fig. 1). UNICEF/WHO[5] reported that four out of every ten persons without access to clean drinking water are in sub-Sahara Africa. In spite of this statistic, about $75 \%$ of the population within the sub-Sahara Africa rely on groundwater sources for clean drinking water[4, 6-8].

Nigeria is strategic among the sub-Sahara Africa countries mainly because of its current and projected population. It is the opinion of the international development committee of the House of Commons that the failure of Nigeria to meet the MDG is the failure of Africa. This is because one in every five African is a Nigerian[9]. Unfortunately, Nigeria receives the least support among 
SSA countries from aid institution, thus contributing to the slow rate of achieving MDG7c[10]. With a growth rate of $3 \%$, Nigeria's growth rate is one of the highest in the world. The country's population became more than tripled within 50 years $(1960-2010)$. If this trend is repeated, it means Nigeria might have a population of 320 million people by 2060. The population factor directly impacts on demand for water, thus making it a major consideration for water planners.

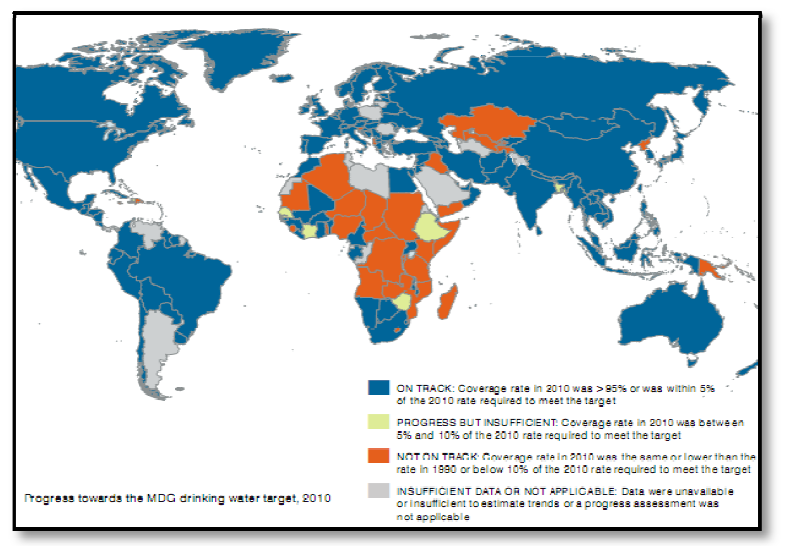

Fig 1. Countries off the track of achieving $M D G 7 c$ are shown in orange shade (Source: [5])

\subsection{Chronicle of Water Supply in Nigeria}

Groundwater development in Nigeria began as far back as 1917 when the Nigeria Geological survey (NGS) was established with part of its objectives being the determination of a geological map for the country and prospection for groundwater in the arid regions of the northern parts of the country. It was found that the country is comprised of two main types of groundwater formations namely the pore-type water in stratified rocks and fissuretype water found in crystalline rocks (Fig. 2). It is to the credit of NGS that the concrete lined hand dug well was introduced into Nigeria around 1928, a technique that is still widely used across the country. The NGS proceeded to upgrade the prospecting for water from hand dug wells to drilled wells in 1938. In 1963, the US Geological Survey partnered with the NGS in conducting an extensive survey of the Sokoto and Chad basins, both within the northern (arid) sections of the country[11].

In 1976, the Federal ministry of water resources (FMWR) and its subsidiaries of eleven river basin development authorities (RBDA) were created and merged with the water section of the NGS. The twelfth RBDA was created at a later date. The FMWR was charged with the responsibility of managing the water resources of the country, provision of water for irrigation and municipal supply, basic hydrological data collection, storage and analysis for national water planning purposes[13]. These are further complemented by State water agencies (SWA) in the thirty six states of the federation and the federal capital territory[10-11,13].
In 1976, the Federal ministry of water resources (FMWR) and its subsidiaries of eleven river basin development authorities (RBDA) were created and merged with the water section of the NGS. The twelfth RBDA was created at a later date. The FMWR was charged with the responsibility of managing the water resources of the country, provision of water for irrigation and municipal supply, basic hydrological data collection, storage and analysis for national water planning purposes[13]. These are further complemented by State water agencies (SWA) in the thirty six states of the federation and the federal capital territory[10-11, 13].

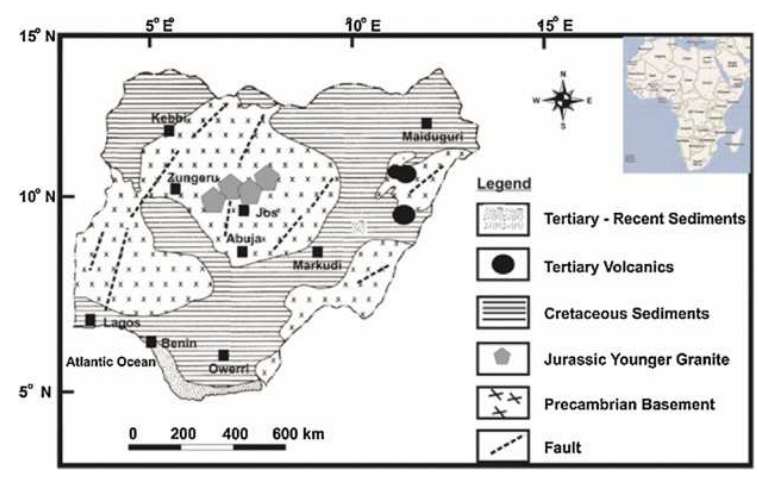

Figure 2. Geological Map of Nigeria (source:[12])

\section{Challenges to Sustainable Groundwater Use in Nigeria}

Groundwater withdrawal is in itself not wrong. Neither is groundwater abstraction by private individuals wrong. However, anthropogenic activities always have impact on the environment. This is more so when a large and increasing proportion of the population continue to impact on groundwater due to factors that can be regulated. Some of these factors are:

\subsection{Insufficient Funding}

The performance of FMWR, the RBDAs and SWAs and has been less than efficient due to insufficient and unsustainable public spending. A breakdown of the national budget reveals that $70 \%$ of the budget is expended on recurrent expenditures such as salaries, staff allowances, rudimentary maintenance of facilities and skeletal services. This leaves $30 \%$ of the budgetary allocation for capital expenditures[10,14]. The Nigerian national budget for the period 2002 to 2011 is presented in Table 1.

From Table 1, it can be observed that allocation to water resources development in Nigeria has not risen consistently with population increase, thus suggesting that increasing water demands have not been factored into budgetary allocations. The table also shows that over the period of ten years, investment in provision of water amounts to an average of $\$ 0.30 /$ capita/annum. In contrast, analysis shows that aid for water from donor countries towards the provision of water for MDG7c amounted to about 
$\$ 1.1 /$ capita/annum for the period 1996 - 2001[16]. Rationally, grants from external sources ought to be less than National allocation. Since this is in reverse, it can be deduced that the country may not have the capacity to sustainably meet its obligation in the provision of water for its citizens. This deduction becomes relevant when compared to the fact that about $34 \%$ of the population obtain water for domestic use from surface water bodies and other unsafe sources[17].

Table 1. Brief summary of Nigeria's budget allocation for the past ten years ( $\square$ billion)

\begin{tabular}{|c|c|c|c|c|c|c|}
\hline Year & $\begin{array}{c}\text { Total Expenditure } \\
\text { (Billion Naira) }\end{array}$ & $\begin{array}{l}\text { Allocation to } \\
\text { Water Supply } \\
\text { (Billion Naira) }\end{array}$ & $\begin{array}{c}\text { allocation to Water } \\
\text { supply (USD million) }\end{array}$ & $\begin{array}{c}\text { Population } \\
\text { (million) }\end{array}$ & $\begin{array}{c}\text { Per capita/per } \\
\text { annum investment } \\
\text { (cents) }\end{array}$ & $\begin{array}{c}\text { Percentage of Water } \\
\text { Supply to Total } \\
\text { Expenditure }(100 \%)\end{array}$ \\
\hline 2002 & 724.5 & 5.5 & 34.4 & 129 & 8 & 0.76 \\
\hline 2003 & 921.2 & 6.4 & 40.0 & 133 & 9 & 0.69 \\
\hline 2004 & 1125.1 & 18.5 & 115.6 & 136 & 30 & 1.64 \\
\hline 2005 & 1478.6 & 26.2 & 163.8 & 139 & 35 & 1.77 \\
\hline 2006 & 1586.8 & 29.7 & 185.6 & 143 & 39 & 1.87 \\
\hline 2007 & 2116.1 & 22.7 & 141.9 & 146 & 29 & 1.07 \\
\hline 2008 & 3107.8 & 28.0 & 175.0 & 150 & 35 & 0.90 \\
\hline 2009 & 2776.9 & 47.7 & 298.1 & 154 & 58 & 1.72 \\
\hline 2010 & 3266.2 & 37.5 & 234.4 & 158 & 46 & 1.15 \\
\hline 2011 & 3542.0 & 20.4 & 125.0 & 162 & 23 & 0.58 \\
\hline
\end{tabular}

Source:[14-15]; NB: NGN160 = USD 1

Aside from national budgetary allocation, international aid has been another very important source of funding for water projects in Nigeria. However, this also has not resolved the difficulty of water provision as Nigeria is still classified among water short nations[5]. USAID[10] reported that Nigeria receives the least sum in aids in the Sub-Sahara Africa. Gleick[16] also reported that more than half of global aid for the provision of water and sanitation was given to just ten countries while countries where about $60 \%$ of their population lacked access to clean drinking water received just $12 \%$ of the funds.

\subsection{Hydrological Factors}

Hydrologically, groundwater is inseparable from surface water. Therefore, variations in either one affect the entire hydrology system. Annual rainfall in Nigeria varies between $250 \mathrm{~mm}$ in the arid north and $4000 \mathrm{~mm}$ in the rainforests in the south[18]. Paradoxically, the economy of the arid north is more agriculture-based than the south. Therefore, the northern section of the country requires a lot of irrigation for the cultivation of produces such as cotton, wheat, onions, tomatoes, millet, sorghum, and groundnuts which is sold in all parts of the country. The northern part of the country also produces most of the beef consumed by the rest of the country. Therefore, the lack of national capacity to supply piped water coupled with low precipitation has led to heightened use of groundwater in northern Nigeria[10].

\subsection{Infrastructure Overload}

In southern Nigeria, the highest demand for water arise from municipal water supply, industries, and agriculture. Due to job opportunities and other factors, nearly $27 \%$ of Nigeria's population live in the eight coastal states of the country while the remaining 28 States and the Federal capital territory accommodate the rest of the population[19].
Moreover, over $60 \%$ of industries in Nigeria, all banks headquarters, and the headquarters of several other international agencies are concentrated in Lagos state[19], thus serving as an attraction for job seekers. This high population density and rural-urban migration in selected states of the country has led to rapid urbanization with attendant pressure on available infrastructure. As an example, the infrastructure in Lagos which was designed for one million people currently supports a population of more than 15 million people[9]. Thus, the absence of expansion programmes and/or maintenance of existing infrastructure has led to infrastructure overload, and in many cases, abandonment. This leaves a vast proportion of the population, industries and small scale enterprises fewer choices among which is groundwater exploitation.

\subsection{Weak Institutions}

Weak institutions and governance systems is counter development. The weakness of the institutions is linked to weak enforcement of the existing policies, laws and regulation. Poor management and incompetent managers also contribute significantly to the weak institutions The SWAs, for instance, are unable to meet up with the responsibility of providing water for people in their states partly because public water utilities are being operated without sound accounting principles[20]. Water is often provided free of charge and in many cases, unaccounted water is as high as $83 \%[20]$. This inefficient and unsustainable water provision system has run aground many SWAs.

\subsection{Data Management System}

Without complete information on the hydro-geological systems in the country information, it becomes impossible to model the aquifer systems, identify fossil aquifers for special resource administration or to enforce restrictions on 
purposes for which a user might be licensed to withdraw groundwater as is being practiced in developed nations. It also becomes difficult to make informed decisions on policies and regulations that make for sustainable use of water from such formations. Fossil aquifers are also known as non-renewable underground water reservoirs because of their extremely slow rate of recharge[21]. It often takes several hundreds to thousands of years to have significant accumulation of water in them. These aquifers are often characterized with very clean water and are mostly found in arid regions[21-22]. An example of fossil aquifer in Nigeria (but which shares boundary with five other countries) is the Chad basin with reserves of $170,000-350,000 \mathrm{Mm} 3$. It is being exploited at the rate of $250 \mathrm{Mm} 3 /$ annum but is being recharged at a rate of less than $1 \mathrm{Mm} 3 /$ annum[21-22]. At the current rate, it would be exhausted between 680-1400 years. This is based on the assumption that it is not hydraulically linked to an adjacent draining aquifer. This type of aquifer ought not to be left to the whims of anyone because of its value and depleting nature.

In terms of hydrological data collection, storage, and analysis, the RBDAs operate below capacity. Most of the RBDAs still operate analogue systems of data recording. In places where computers exist, epileptic electricity supply prohibits their use, thus leading to inefficient data collection and storage. With the expected volume of data to be managed, data analysis becomes tedious. This in turn leads to limited decision taking at national level on hydrological matters.

\subsection{Resource Protection Through Regulations and Enforcement}

In terms of resource protection, the National Environmental Standards and Regulations Enforcement Agency (NESREA) was established in 2007 to replace the Federal environmental protection agency (FEPA) which operated from 1988 to 2007[23]. The latter was scrapped due to reported operational lapses[23]. However, due to other perceived more environmentally sensitive issues such as oil spills and hazardous wastes management, NESREA has not paid adequate attention to surface and groundwater resources[23]. The first known environmental regulation on surface and groundwater was published only in 2011 with its objective being 'to restore, enhance and preserve the physical, chemical and biological integrity of the nation's surface and ground waters and to maintain existing water uses'[23-24]. This regulatory provision appears to be a step in the right direction if it can be given the necessary attention and drive for accomplishment.

\subsection{Indiscriminate Groundwater Exploitation}

Due to lack of capacity on the part of responsible institutions to meet with the ever increasing demands for water in Nigeria, there has been heightened and unrestrained exploitation of groundwater. Nearly anyone that can afford to sink a well has gone ahead to do so without recourse to expert advice on hydro-geological data, safe yield, technology, or excess draw down in water table[11]. This chaotic situation has given rise to affiliated problems such as the involvement of unqualified well drillers and capital loss. With frequent reports of failed wells, failed pumps[11], and groundwater contamination arising from drilling mud and septic tanks interferences, capital flight arising from the systemic failure would be enormous when quantified.

\section{The Way Forward}

In Nigeria, all land and mineral resources within it are held in trust for the people by the Governor of each State Government through the land use Act of 1978[25]. By extension, it could be deduced that all water resources ought to be held in trust also. However, this is not clearly defined. The act allows persons who wish to build on a piece of land the right of ownership for 99 years once a certificate of occupancy has been obtained. This may be renewed at expiration. However, if crude oil or gold is discovered on the same land, the State reserves the right of ownership of such resources and the right to revoke such certificate of occupancy in order to secure the resource in public trust. In the case of groundwater however, the State has been silent, probably because it recognizes its own incapacitation at providing water for people. Thus, the riparian system is very much in use. The occupiers of the land simply exploit the water at will without any form of permit, control, or penalty. It is therefore suggested that control of groundwater resources within each state should be tied to the 1978 land use act. That is, groundwater should be accorded the same protective status as precious resources such as gold and crude oil. Therefore, special permits should be attached to rights to own a well. However, in view of the high poverty rate in the country and the need to achieve the MDG on clean drinking water, licensing for the prospection of water should not attract additional charges. Rather, the licensing should impose additional responsibilities on prospective well owners in order to make them exploit the wells sustainably and with the full knowledge that the groundwater resource is not theirs to abuse at will. Responsibilities that could be attached to obtaining a license to exploit groundwater should include:

i. Only qualified and certified operators could be allowed to drill wells.

ii. Private drilling operators should be required to submit data to a central pool. This will help reduce costs of exploratory drilling and help furnish decision makers with information on sub-regional reconnaissance.

iii. Private drilling should also be fitted with remote sensing meters to monitor the withdrawal rates and to plan exit strategies.

Furthermore, in order to begin to take control of its water resources, Nigeria needs to upgrade its entire water 
resources data base management system. There should be collaborative effort between the FMWR, its subsidiaries, and its SWA counterparts in order to achieve this since there is always benefits in synergizing efforts and information sharing. Also, steps need to be taken to complete hydro-geologic mapping of the entire country in order to characterize and take inventory of all its water bearing formation. The FMWR and SWAs may be designed to be a 'one-stop shop' where detailed information on national water resources and prospecting licenses can be obtained. While the FMWR pre-occupies itself with the hydro-geological mapping, the SWAs should embark on sub-regional reconnaissance. This reconnaissance could be done by combining satellite imagery and aeromagnetic surveys with ground observations of hydro-geological features in order to obtain greater details on sub-surface conditions of groundwater resources in their immediate vicinity[22]. The SWAs may also need to be tasked with the duty of conducting regular exploratory drillings to determine individual aquifer properties such as depth, thickness, water quality, direction of flow, and other aquifer hydraulic properties. The cost of doing this may be defrayed by putting a system in place whereby those licensed to prospect for water are required by law to provide the coordinates of the proposed well, return core samples and provide other affiliated information. This information could be archived in a central data-base system for future analysis and decision taking on the host aquifer systems.

With respect to funding, budgetary allocations and implementation, the culture of transparency and accountability should be promoted. More results could be achieved with less monetary resources. The issue of fiscal accountability was mentioned by some aid agencies as a major concern in Nigeria[9-10,26]. This may also be a reason why aid institutions have been committing less financial resources to the provision of water resources in Nigeria in spite of the strategic position of Nigeria in subSahara Africa and the world. Seemingly, the Federal Government cannot solve the challenge of provision of potable water supply for most of its citizens because of competing national needs and debt burdens. It is also apparent that most of the population cannot help themselves because of the high rate of poverty. It is an established fact that the poor pay more per litre for water all over the world. This burden on the poor should be alleviated by allowing the aid from donor organizations to reach them. The opportunity afforded by aid institutions should therefore be encouraged and maximized by returning value for every dollar invested.

In addition, global attention is shifting from the provision of more infrastructures meant for the provision of more water to the efficient use of what is available. This has been described as the 'soft path' approach to water resources management[16, 27]. A situation where $83 \%$ of water provided by SWAs cannot be accounted for underscores the need to upgrade the agency's operational efficiency. If the surface water resources are well protected, managed and channelled, there would be less pressure on groundwater resources, thereby preserving them for future generations and/or contingent situations. The efficient use of water can be achieved by strengthening the existing water management institutions and giving more bite to regulations enforcement. Polluters should be made to pay and everyone should be made aware that groundwater is a common wealth that should be protected.

\section{Conclusion}

The current study reviewed the origin and the present status of groundwater exploration in Nigeria. Agriculture, municipal water supply and industrial/manufacturing concerns were identified as the largest consumers of groundwater. It found that currently, as much as $60 \%$ of Nigerians utilize groundwater for domestic purposes. The inordinate demand for groundwater in Nigeria has been exacerbated by inadequate and ill-maintained infrastructure, a short fall in public utility supply of water, improper management of available financial resources, inadequate funding of water and sanitation programmes, ineffective and ambiguous policies and regulations where it concerns groundwater resources, pollution of available surface water bodies, and availability of relatively cheap technology for groundwater exploitation. This has led to serious abuse of groundwater resources as evidenced by incursion of untrained personnel in the business of groundwater exploitation, high rate of failure of deep wells, indiscriminate well sinking resulting in excessive draw down and general lowering of the water table. It was recommended that all groundwater resource in Nigeria should be classified as a common wealth and accorded the same status as crude oil by insisting that licenses should be obtained before prospecting. In view of the high poverty rate among most Nigerians, it was further recommended that no additional charge should be attached to licensing beside from the cost of purchasing the land. However, additional responsibilities which would ensure that the resource is handled with care should be imposed on all prospective users. It was further suggested that efficient use of available water resources should be given more emphasis than the provision of more water.

\section{References}

[1] Shah T, Burke J, Villholth K (2007) Groundwater: a global assessment of scale and significance. In: Water for Food, Water for Life: A Comprehensive Assessment of Water Management in Agriculture. Earthscan and Colombo: International Water Management Institute, London.

[2] OECD. (2012). Development Co-operation Report 2012: Lessons in Linking Sustainability and Development, OECD Publishing. Available at: http://dx.doi.org/10.1787/dcr2012-en. Accessed 14 December 2012. 
[3] IAH (2010). IAH Commission on Groundwater and Climate Change. Available at http://www.iah.org/gwclimate/gw_cc.html. Accessed 14 December 2012

[4] IIED (2010). Groundwater, self-supply and poor urban dwellers: A review with case studies of Bangalore and Lusaka. Edited by Gronwall, J.T., Mulenga, ., and McGranahan, $\mathrm{G}$ for International Institute for Environment and Development, London. ISBN: 978-1-84369-770-1.

[5] UNICEF/WHO (2012). Progress on drinking water and sanitation: 2012 update. UNICEF and World Health Organization. ISBN: 978-92-806-4632-0.

[6] Ogunba, A. (2011). Nigeria's New Environmental Laws: What Implications for Groundwater Protection and Sustainability? Colloquium, South Africa.

[7] Omole D.O. (2010), Water Quality Modelling: Case study of the Impact of Abattoir Effluent on River Illo, Ota, Nigeria. LAP Lambert Academic Publishing GmbH \& Co. KG, Saarbrücken, Germany. ISBN: 978-3-8433-7034-9.

[8] AWV. (2009). The Africa water vision for 2025: Equitable and sustainable use of water for socioeconomic development. UN Water/Africa. Available at http://www.icp-confluence-

sadc.org/sites/default/files/African $\% 20$ Water $\% 20$ Vision $\% 2$ 02025.pdf. Accessed 1 SEPT 2012.

[9] IDC (2009). DFID's Programme in Nigeria. International Development Committee. Eighth Report of Session 200809, vol. 1, House of Commons, London.

[10] USAID (2010). NIGERIA Water and Sanitation Profile. Available http://www.washplus.org/sites/default/files/nigeria.pdf Accessed 14 Dec. 2012

[11] Eduvie M.O. (2006). Borehole Failures and Groundwater Development in Nigeria. National Seminar on the Occasion of Water Africa Exhibition (Nigeria 2006), Lagos, Nigeria. Available http://www.nwri.gov.ng/userfiles/file/Borehole_Failure in Nigeria.pdf Accessed 20 Dec. 2012.

[12] Adepelumi, A. A. and Fayemi, O. (2012). Joint application of ground penetrating radar and electrical resistivity measurements for characterization of subsurface stratigraphy in Southwestern Nigeria. J. Geophys. Eng. 9; pp 397-412.

[13] FMWR (2000). National Water Supply and Sanitation Policy. 1st edition, Fed Republic of Nigeria. Available at: http://www.nwri.gov.ng/userfiles/file/National Water_Supp ly_and_Sanitation_Policy.pdf. Accessed 20 December 2012.

[14] CBN, 2012. Annual report for the year ended $31^{\text {st }}$ of December. Available at: http://www.cenbank.org/Out/2012/publications/reports/rsd/a rp-
2011/2011\%20Annual\%20Report_Complete\%20Report.pdf Accessed 26 May 2013.

[15] WORLD BANK, 2012. World development indicators and global development finance. Available at: http://www.google.co.uk/publicdata/explore?ds=d5bncppjof 8f9_\&met_y $=$ sp_pop_totl\&idim=country:NGA\&dl=en\&hl= en\&q=nigeria\%20population Accessed: December 29, 2012.

[16] Gleick, P.H., Allen, L., Christian-Smith, J., Cohen, M.J., Cooley, H., Herberger, M., et. al. (2012). The World's water volume 7: The Biennial Report on Freshwater resources.

[17] Longe, E.O., Omole, D.O., Adewumi, I.K. and Ogbiye, A.S. (2010). Water Resources Use, Abuse and Regulations in Nigeria. Journal of Sustainable Development in Africa, Vol. $12(2): 35-44$.

[18] Adekunle, I. M., Adetunji, M. T., Gbadebo, A. M. and Banjoko, O. B. (2007). Assessment of Groundwater Quality in a Typical Rural Settlement in Southwest Nigeria. Int. J. Environ. Res. Public Health, 4(4), 307-318.

[19] Omole, D.O. and Isiorho, S.A. (2011). Waste Management and Water Quality Issues in Coastal States of Nigeria: The Ogun State Experience. Journal of Sustainable Development in Africa, 13(6):207-217.

[20] AfDB/OECD. African Economic Outlook: Nigeria (2007);K auffmann, Celine and Perard, Edouard. New Partnership for Africa's Development (NEPAD)/OECD. Stocktaking of the water and sanitation sector and private sector involvement $\mathrm{i}$ n selected African countries (2007).

[21] Margat, J., Foster, S. and Droubi, A. (2006). Concept and importance of non-renewable resources. In Foster, S. and Loucks, D.P. (Editors), 'Non renewable groundwater resources'. UNESCO Paris.

[22] Shaminder, P., Margat, J., Yurtsever, Y., and Wallin, B. (2006). Aquifer characterisation techniques. In Foster, S. and Loucks, D.P. (Editors), 'Non renewable groundwater resources'. UNESCO Paris.

[23] Ladan, M.T. (2012). Review of Nesrea Act 2007 and Regulations 2009-2011: A New Dawn in Environmental Compliance and Enforcement in Nigeria. Law, Environment and Development Journal 8(1): p. 116-140.

[24] FRN (2011). Environmental regulation on surface and groundwater, S.I. No. 22, Gazette No. 49, Vol. 98 of $24^{\text {th }}$ May, 2011 of the Federal Republic of Nigeria, Abuja.

[25] FRN (1978). Land Use Act (1978) C.A.P. 2002. Federal Republic of Nigeria.

[26] DFID NIGERIA (2012). Operational Plan 2011-2015. Available at http://www.dfid.gov.uk/documents/publications1/op/nigeria -2011.pdf. Accessed 29 December 2012.

[27] Gleick, P.H. (2003). Global freshwater resources: Soft path solutions for the $2^{1 \text { st }}$ century. Science, $302(1524)$. 